\title{
Pathophysiology of hepatitis C: case-control study of cell reactivity and adaptation tension level in patients with chronic HCV-infection at Bukovyna (South-Western Ukraine region)
}

\author{
A. S. Sydorchuk, V. D. Moskaliuk, I. V. Balaniuk, L. I. Sydorchuk \\ Higher state educational institution of Ukraine "Bukovinian State Medical University", Chernivtsi, Ukraine
}

Key words:

hepatitis C, adaptive stress, cell reactivity, chronic course, immune response, Bukovyna.

\section{Zaporozhye}

medical journal

2017; 19 (2), 156-161

DOI

10.14739/2310-1210.

2017.2.95675

E-mail:

sidorchuk@bsmu.edu.ua

Introduction: Hepatitis $\mathrm{C}$ is a disease with a significant global impact. It had estimated that there are 2-5 million HCV-positive persons in Europe. It is very difficult to predict the individual course of hepatitis $\mathrm{C}$ due to the many factors influencing the disease progression. Cell reactivity and level of adaptive tension had been considered as additional parameters for the evaluation of individual immune response and may assist to predict an intensity of autoimmune liver inflammation caused by HCV.

Research purpose: This article discusses about investigation of cell reactivity and level of adaptation tension for better estimation of pathophysiology of chronic hepatitis $\mathrm{C}$ especially in prediction of its clinical course.

Materials and methods. The article presents the results of determination of adaptation tension level and cell reactivity in 31 infected persons hospitalized in Hepatology Center of Chernivtsi Municipal Clinical Hospital in 2015. Parameters of immunocompetent cells and immune-hematologic indexes were calculated.

Results. It had been established that in patients with chronic hepatitis C level of adaptation decreased on $12.20 \%$. Abnormalities of adaptation processes were determined in $70.97 \%$ of enrolled patients : in $22.58 \%$ of cases - adaptation level was determined in the zone of stress reaction, and in $48.39 \%$ in the zone of reaction on training. Increase of intoxication index on $33.33 \%$ was determined; proper endogenic intoxication triggered in chronic phase a certain hepatic cells cytolysis caused by viral reproduction with subsequent immune system reaction. Cellular reactivity of organism of patients with chronic hepatitis $\mathrm{C}$ decreased on $32.03 \%$, that was confirmed by elevation on $81.25 \%$ of nuclear index of endotoxicosis level.

Conclusions. Cell reactivity index in chronic hepatitis C patients decreased on $32.03 \%$, that leads to elevation of haematologic intoxication index on $32.25 \%$. This confirmed that intoxication had been going over interstitial space and manifested up to toxicosis in circulatory blood. Nevertheless, increased nuclear index on $81.25 \%$ certified the presence of middle level of endotoxicosis. Parenchymal damage of cell membranes could lead to significant metabolic disorders, which plays a major role of liver fibrosis formation. It proved the important meaning of adaptive index in each individual patient to consider it for prediction of clinical course.

Киючові слова:

гепатит C, адаптивний стрес, кмітинна реактивність, імунна віАповіАь, Буковина.

Запорізький медичний журнал. - 2017.

T. 19, № 2(101).

C. $156-161$

\section{Патофізіологія гепатиту С: «випадок-контроль” дослідження кмітинної реактивності та рівня адаптаційного напруження у хворих із хронічною HCV-інфекцією на Буковині (Південно-Західний регіон України)}

\section{А. С. Сидорчук, В. А. Москалюк, І. В. Баланюк, А. І. Сидорчук}

Гепатит C - хвороба, що має суттєве світове значення. Нараховують майже 2-5 мільйонів гепатит С-позитивних осіб в Європі. Дуже важко передбачити індивідуальний перебіг гепатиту C, бо є багато фракторів, що впливають на прогресування хвороби. Клітинна реактивність і рівень адаптаційного напруження вважаються додатковими параметрами для оцінювання індивідуальної імунної відповіді, які можуть спрогнозувати інтенсивність аутоімунного запалення в печінці, що спричинене вірусом гепатиту C.

Мета роботи. У цій статті дискутують про дослідження клітинної реактивності та рівня адаптаційного напруження для кращого оцінювання патофізіології хронічного гепатиту С, особливо щодо прогнозування його клінічного перебігу.

Матеріали та методи. Представлені результати детермінації рівня адаптаційного напруження та клітинної реактивності у 31 хронічно інфікованого пацієнта, які були ушпиталені до обласного гепатологічного центру при КМУ «Обласна клінічна лікарня м. Чернівці» у 2015 році. Вивчені показники імунокомпетентних клітин та розраховано відповідні імуногематологічні індекси.

Результати. Встановили, що в пацієнтів із хронічним гепатитом С рівень адаптації знижений на 12,2\%. Детерміновано, що у 70,97\% залучених пацієнтів є порушення адаптаційних процесів: у 22,58 \% випадків - адаптаційний рівень у зоні стресу, у 48,39 \% - у зоні реакції тренування. Встановлене вірогідне зростання інтоксикаційного індексу на 33,33 \%; власне ендогенна інтоксикація запускає у хронічній фазі цитоліз печінкових клітин, що зумовлений вірусною репродукцією з наступною реакцією імунної системи. Клітинна реактивність організму пацієнтів із хронічним гепатитом С знижена на 32,03\%, що підтверджено підвищенням на 81,25\% ядерного індексу рівня ендотоксикозу.

Висновки. Клітинна реактивність у пацієнтів із хронічним гепатитом С знижена на 32,03 \%, що призводить до зростання гематологічного індексу на $32,25 \%$. Це підтверджує те, що інтоксикація виходить за межі інтерсиційного простору та маніфестує у вигляді токсикозу, що спостерігаємо в циркулюючій крові. До того ж, зростання ядерного індексу на 81,25\% показує наявність середнього рівня ендотоксикозу. Паренхімальне пошкодження клітинних мембран може призводити до істотних метаболічних зрушень, що відіграє велику роль у формуванні фіброзу печінки. Це засвідчує важливе значення адаптивного індексу в кожному індивідуальному випадку для розуміння прогнозування клінічного перебігу. 


\section{Патофизиология гепатита С: "случай-контроль" исследование клеточной реактивности и уровня адаптационного напряжения у больных с хронической HCV-инфекцией на Буковине (Юго-Западный регион Украины)}

\section{А. С. Сидорчук, В. А. Москалюк, И. В. Баланюк, А. И. Сидорчук}

Гепатит С является болезнью с важным мировым значением. Насчитывается около 2-5 миллионов гепатит С-положительных лиц в Европе. Очень тяжело предусмотреть индивидуальное течение гепатита С из-за того, что существует много факторов, которые влияют на прогрессирование болезни. Клеточная реактивность и уровень адаптационного напряжения считаются дополнительными параметрами для оценки индивидуального иммунного ответа, которые могут спрогнозировать интенсивность аутоиммунного воспаления в печени, вызванного вирусом гепатита С.

Цель работы. В этой статье дискутируют об исследовании клеточной реактивности и уровня адаптационного напряжения для лучшего оценивания патофизиологии хронического гепатита С, особенно касательно прогнозирования его клинического течения.

Материалы и методы. Статья представляет результаты детерминации уровня адаптационного напряжения и клеточной реактивности у 31 хронически инфицированного пациента, госпитализированного в областной гепатологический центр КМУ «Областная клиническая больница г. Черновцы» в 2015 году. Изучены показатели иммунокомпетентных клеток и рассчитаны соответствующие иммуногематологические индексы.

Результаты. Установлено, что у пациентов с хроническим гепатитом С уровень адаптации снижен на 12,2\%. Детерминировано, что у 70,97\% обследованных пациентов есть нарушение адаптационных процессов: в 22,58 \% случаев адаптационный уровень - в зоне стресса и в 48,39 \% - в зоне реакции тренировки. Установлено достоверное увеличение интоксикационного индекса на 33,33\%; собственно эндогенная интоксикация запускает в хронической фразе цитолиз печёночных клеток, обусловленный вирусной репродукцией с последующей реакцией иммунной системы. Клеточная реактивность организма пациентов с хроническим гепатитом С снижена на 32,03 \%, что подтверждено повышением на 81,25\% ядерного индекса уровня эндотоксикоза.

Выводы. Клеточная реактивность у пациентов с хроническим гепатитом С снижена на 32,03\%, что приводит к росту гематологического индекса на 32,25\%. Это подтверждает то, что интоксикация выходит за пределы интерстиционного пространства и манифестирует в виде токсикоза, что наблюдаем в циркулирующей крови. Более того, рост ядерного индекса на 81,25\% свидетельствует о наличии среднего уровня эндотоксикоза. Паренхимальное повреждение клеточных мембран может приводить к существенным метаболическим сдвигам, играет большую роль в формировании фиброза печени. Это подтверждает важное значение адаптивного индекса в каждом индивидуальном случае для понимания прогнозирования клинического течения.

\section{Background}

Hepatitis $\mathrm{C}$ is a disease with a significant global impact. According to the $\mathrm{WHO}$, about 150 million people are chronically infected with hepatitis $C$ virus, and more than 350 million people die every year from hepatitis C-related diseases (cirrhosis, hepatocellular carcinoma) [2,11]. The cause of hepatitis $\mathrm{C}, \mathrm{HCV}$, is an enveloped, spherical, single-stranded RNA virus belonging to the Flaviviridae family. The natural targets of HCV are hepatocytes and, possibly, B-lymphocytes. Viral clearance is associated with the development and persistence of strong virus-specific responses by cytotoxic T lymphocytes and helper T cells [3].

Hepatitis $C$ virus is a blood-borne virus and the most common modes of infection are through unsafe injection practices, inadequate sterilization of medical equipment, and the transfusion of unscreened blood and blood products [8].

The incubation period lasts 15-150 days for the acute phase, but only $15 \%$ of patients will present the latter. Chronic symptoms appear 20-40 years after contamination. Symptoms of cirrhosis include weakness, anorexia, weight loss, and gynecomastia in men, a skin eruption on the palms, blood-clotting disorders, and telangiectasia [10].

There are considerable region differences. In some countries, e. g., Egypt, the prevalence is as high as $20 \%$. According to different estimates, up to 3 percent of people in Ukraine are ill with viral hepatitis C. There was no official statistics before 2009 and registration of people ill with chronic viral hepatitis $C$ had not carried out in Ukraine until 1 July 2009. Detection rate of antibodies (anti-HCV) demonstrated that the percentage of $\mathrm{HCV}$ carriers varies in Eastern Europe from 1.5 to $4 \%$. The annual incidence rate of acute hepatitis $\mathrm{C}$ in Europe is 1-3 cases per 100 thousand populations [10]. In Western Europe, the frequency of HCV $0.4-3 \%$. There are 6 genotypes of $\mathrm{HCV}$, and genotypes $1 \mathrm{a}$ and $1 \mathrm{~b}$ are more distributed [9].

In most infected people, viremia persists and is accompanied by variable degrees of hepatic inflammation and fibrosis. Findings from studies suggest that at least $50 \%$ of hepatocytes may be infected with $\mathrm{HCV}$ in patients with chronic hepatitis $\mathrm{C}$.

RNA-dependent RNA polymerase, an enzyme critical in HCV replication, lacks proofreading capabilities and generates a large number of mutant viruses well known as quasi species. These represent minor molecular variations with only $1-2 \%$ nucleotide heterogeneity. HCV quasi species pose a great challenge to immune-mediated control of $\mathrm{HCV}$ and could explain the variable clinical course and the difficulties in vaccine development $[3,9]$.

Hepatocytes, monocytes/macrophages, B-lymphocytes and polymorphonuclear leukocytes are targets of HCV. Direct infection of these immune cells determine immunological disorders of innate and adaptive immunity, which are registered in more than half of patients with chronic HCV-infection [7]. In chronically infected patients, the T-cell response to the HCV is polyclonal and multispecific, although it is not as strong as the response in acutely infected patients who demonstrated a more vigorous T-cell response. Importantly, viral clearance in acutely infected patients is associated with strong CD4 (+) mediated T-cell response. Thus, the dominant
Ключевые слова: гепатит $\mathrm{C}$, адаптивный стресс, клеточная реактивность, иммунный ответ, Буковина.

\section{Запорожский} медицинский журнал. - 2017. T. 19, № 2(101). C. 156-161 
cause of viral persistence during HCV infection may be due the development of a weak antiviral immune response to the viral antigens, with corresponding inability to eradicate infected cells. Liver cell damage may extend from virally infected to uninfected cells via soluble cytotoxic mediators and recruitment and activation of inflammatory cells forming the necrotic inflammatory response [8].

By literature data, up to $80 \%$ of patients with acute hepatitis $\mathrm{C}$ develop chronic infection that manifests as persistent HCV RNA detected in the blood with / without abnormal liver function tests. Most patients with chronic hepatitis $C$ have no or only mild symptoms, including fatigue, anorexia, and nausea $[2,11]$.

Anti-HCV antibody is not protective, and its level does not necessarily remain elevated in patients with chronic hepatitis $\mathrm{C}$. It is important to investigate the level of adaptation tension in patients with chronic hepatitis $\mathrm{C}$ as well as a cell reactivity status associated with indicators of innate and adaptive immunity [6]. Current study aimed to recognize adaptation processes, and depending on it will be possible to support a prediction of the clinical course of disease and efficacy of holiatry.

Aim of the study was to investigate pathophysiologic mechanisms of cell reactivity and adaptation tension level of the patient's organism with chronic HCV-infection.

\section{Materials and Methods}

Prospective case-control study was conducted within 2015 year at the Municipal Hepatology Center chaired at Chernivtsi Municipal Hospital. 31 patients with chronic hepatitis $\mathrm{C}$ were enrolled. Patients with next gender allocation -17 male patients and 14 female, aged 18-65 years (average age $44.55 \pm 1.14$ ), were admitted to Municipal Hepatology Center and hospitalized for holiatry. The study included patients who had no other exacerbation of chronic diseases but hepatitis $C$. Patients with autoimmune, allergic diseases, tuberculosis and cancer of any localization, as well as patients who got three or more days of therapy with antibiotics were excluded. All persons involved into the study gave written informed consents.

The control group included 30 healthy volunteers $(21$ male and 9 female), aged $46.81 \pm 2.41$. All of them were enrolled for basic study group with preliminary diagnosis of $\mathrm{HCV}$-infection. Presence of HCV and it viral load at the time of admission was atudied by PCR.

In 21 patients «Chronic HCV-infection genotype $1 \mathrm{~b}$, without liver dysfunction» was diagnosed, 7 patients had «Chronic HCV-infection genotype $1 \mathrm{~b}$ with impaired liver function», two patients - «Chronic HCV-infection, genotype 3a without hepatic dysfunction» and one patient - «Chronic HCV-infection, genotype 3b without liver dysfunction». In 24 cases $(77.42 \%)$ of chronic hepatitis $C$ course no liver dysfunction was detected.

All patients and healthy individuals who were enrolled the current study underwent blood tests. Absolute and relative amount of basic populations of immunocompetent cells was determined by traditional method. We determined the following nonspecific adaptive response of the body of patients: stress, training reaction, calm response, and reaction of elevated activation $[1,5,6]$.

We used adaptation index as an integrated test [1]. Cell reactivity was studied with means of determination of leukocytic index of intoxication, endotoxemia nuclear index level, hematologic index of intoxication [4-6].

Cell reactivity and adaptation level in the organisms of patients were determined by the degree of immune disorders for each indicator [4]. Sign «+» indicated hyperproduction of appropriate cell population, and «-» negative value considered the deficit accordingly.

The results of clinic and immunological studies were estimated with methods of variation statistics. Average error $(M \pm m)$ was determined. Certain differences between the averages of samples performed by using t-test Student.

Table 1. Absolute and relative figures of main immune-competent cells of enrolled chronic HCV-infected persons at Bukovyna, $\mathrm{M} \pm \mathrm{m}$

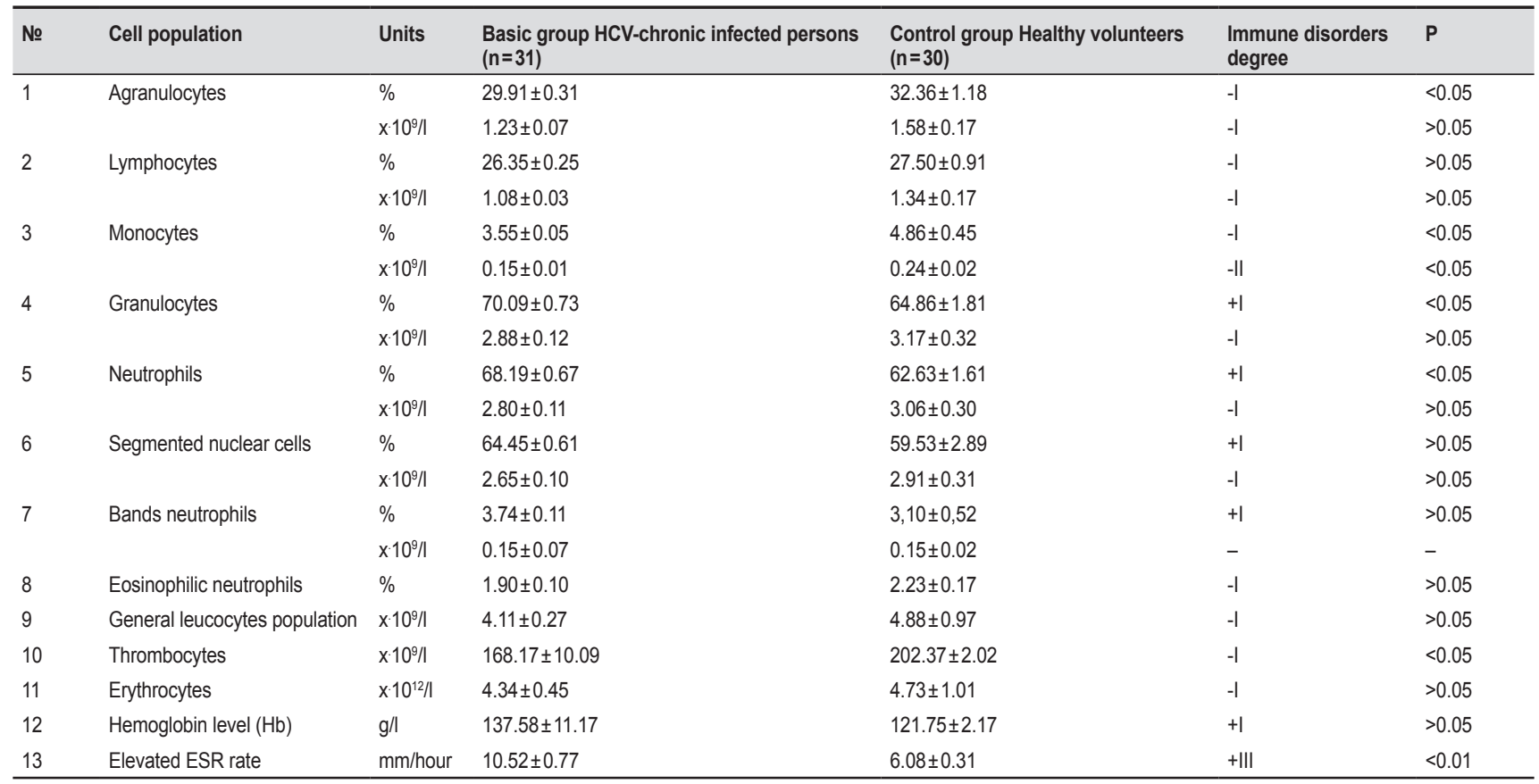


Differences of medium and relative frequencies considered as significant at the level of confidence ( $p$ ) less than 0.05 . The research results proceedings was performed by means of the software Statistica for Windows 5.0 (StatSoft Inc., USA).

\section{Results}

A leading role in providing of adaptation activity of a human organism belongs to immunocompetent cells in circulating blood. Simultaneously system of blood is one of a major transmitters of information about processes that being across the level of tissue structures. All immunocompetent blood cells as a part of peripheral immune system are very sensitive to the changes of environment as well as to internal state of organism. The parameters of absolute and relative amount of basic populations of immunocompetent cells changes can extend up to limit adaptation possibilities of organism. It had evidenced that power mechanism occupies the main place in the processes of adaptation. Use of adaptation reactions will give an opportunity to carry out the individual going near determination of adequacy of adaptation reactions with taking into account of the state of organism. The use of adaptation reactions will give an opportunity to carry out the individual determination of adequacy of adaptation reactions with taking into account the state of the organism.

Results assessment showed changes of absolute and relative amount of basic populations of immunocompetent cells of peripheral blood in patients with HCV-infection. Agranulocytes' relative amount was established on $8.19 \%$ $(p<0.05)$. Consequently, a relative amount of monocytes decreased on $36.90 \%$ and it was accompanied with tendency to decrease of relative amount of lymphocytes on $4.32 \%$. It was observed that absolute amount of monocytes fell down on $60.0 \%$. On this background the relative amount of granulocytic polymorph nuclear leucocytes increased on $8.06 \%(p<0.05)$ due to elevation of relative amount of neutrophils on $8.26 \%$. The absolute amount of thrombocytes diminished on $20.34 \%$ in patients with chronic HCV-infection. All patients envolved in basic group demonstrated increase of erythrocytes sedimentation rate in average on $73.03 \%$.

Values of relative lymphocyte count and segmentic nuclear neutrocytes were assessed as well for determination of adaptation index for every patient. Results of absolute and relative quantities of the basic immuno-competent cells determination in enrolled patients described in Table 1 below.

Detailed comparison analysis of mentioned parameters allowed us to make conclusion about decrease of relative quantity of agranulocytes up to $8.19 \%(p<0.05)$. Moreover relative quantity of monocytes had drop down on $36.90 \%$ and the tendency for decrease of relative lymphocytes amount had observed up to $4.32 \%$. Simultaneously the absolute figure of monocytes had declined up to $60.0 \%$.

It was determined that relative amount of polymorphic nuclear leucocytes was decreased on $8.06 \%(p<0.05)$ due to increase of relative amount of neutrophil granulocytes on $8.26 \%$. Absolute platelet count was reduced by $20.34 \%$. The obtained changes in the absolute and relative amount of major populations of immunocompetent cells of peripheral blood of enrolled patients attest to the systemic inflammatory process, evidence of which wass erythrocyte sedimentation rate significant increase in $73.03 \%$.
Based on the values of relative amount of lymphocytes and segmented neutrophils adaptation index for each patient was assessed [1]. The prognostic value of adaptation index was well-proven. Reaction to the stress, training reaction, reaction of the «calm» activation and reaction of increasing activation of adaptation were assessed (Fig. 1).

Value of adaptation index in patients with $\mathrm{HCV}$-infection and in volunteers being determined in the zone of «reaction on training», but this index for basic group had tendency to going down on $12.20 \%$.

Distribution by individual types of adaptation tension level in patients with chronic HCV-infection at Bukovyna was showed on Table 2.

Each range of values of adaptation index correspondingly answered for adaptation reactions. High values of adaptation index corresponded to the more favorable prognosis of the disease [1,5] (Table 3).

Stress response was diagnosed in 7 patients with $\mathrm{HCV}$-infection, that testifies the unfavorable prognosis of clinical course. Favorable forecast was detected only in 9 $(29.03 \%)$ patients, in majority - $22(70.97 \%)$ it was predicted as unfavorable, that requires not only intensive facilities of treatment, but also an intensive psychological rehabilitation.

\section{Discussion}

It was proven that index of cellular reactivity of organism in patients with $\mathrm{HCV}$ decreased on $32.03 \%$. Haematological index of intoxication after V. Vasiliev increased on $32.25 \%$. Hypothesis about intoxication going outside interstitial liver space and it influence on toxins in circulatory peripheral blood increase was proved. Nevertheless, nuclear index increase on $81.25 \%$ certified the presence of middle level of endotoxicosis. Parenchymal damage of cell membranes could lead to significant metabolic disorders, that plays a major role in liver fibrosis formation [7].

It was established an evident increase of intoxication

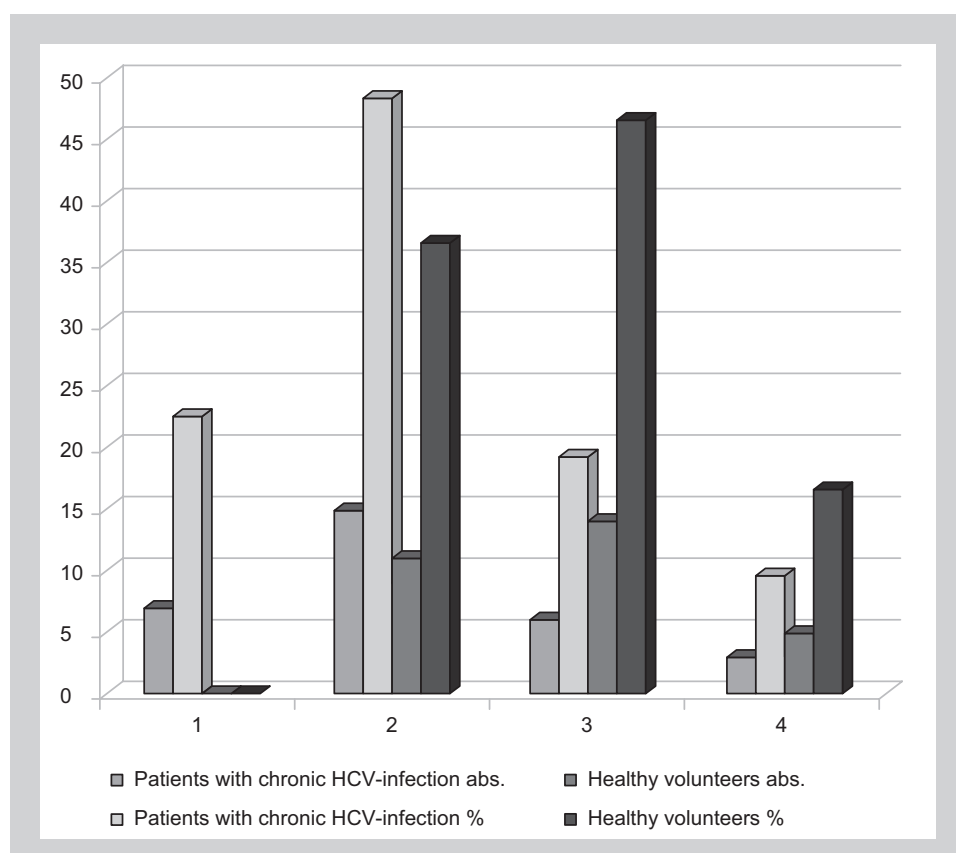

Fig. 1. Level of adaptation tension of organism: 1 - stress reaction; 2 - training reaction; 3 - «calm» activation of adaptation; 4 - increasing activation of adaptation. 
Table 2. Distribution by individual types of adaptation tension level in patients with chronic HCV-infection at Bukovyna, $\mathrm{M} \pm \mathrm{m}$

\begin{tabular}{|c|c|c|c|c|c|c|}
\hline \multirow[t]{2}{*}{ Types of adaptation } & \multicolumn{2}{|c|}{ Patients with chronic HCV-infection $(n=31)$} & \multicolumn{2}{|c|}{ Practically healthy volunteers $(n=30)$} & \multirow{2}{*}{$\begin{array}{l}\text { Level of adap- } \\
\text { tive disorders }\end{array}$} & \multirow[t]{2}{*}{$\mathbf{P}$} \\
\hline & abs. & $\%$ & abs. & $\%$ & & \\
\hline Adaptation index & $0,41 \pm 0,04$ & & $0,46 \pm 0,05$ & & -1 & $>0.05$ \\
\hline Training reaction & 15 & 48.39 & 11 & 36.67 & +11 & $>0.05$ \\
\hline «Calm» activation of adaptation & 6 & 19.35 & 14 & 46.67 & $-\|$ & $<0.05$ \\
\hline Increased activation of adaptation & 3 & 9.68 & 5 & 16.66 & $-\|$ & $>0.05$ \\
\hline
\end{tabular}

Table 3. Cell reactivity of organisms of patients with chronic HCV-infection at Bukovyna, $\mathrm{M} \pm m$

\begin{tabular}{|c|c|c|c|c|}
\hline Immuno-hematologic parameter & $\begin{array}{l}\text { Patients with chronic HCV-infection } \\
(n=31)\end{array}$ & $\begin{array}{l}\text { Practically healthy volunteers } \\
(n=30)\end{array}$ & $\begin{array}{l}\text { Level of adaptive } \\
\text { disorders }\end{array}$ & $\mathbf{P}$ \\
\hline Leucocytic index of intoxication by Ya. Kal-Kalif & $1.66 \pm 0.12$ & $1.57 \pm 0.12$ & +1 & $>0.05$ \\
\hline Leucocytic index of intoxication by V. Rais & $2.14 \pm 0.10$ & $1.97 \pm 0.09$ & +1 & $>0.05$ \\
\hline Leucocytic index of intoxication by S. D. Chimich & $0.28 \pm 0.02$ & $0.32 \pm 0.03$ & -1 & $>0.05$ \\
\hline Haematologic parameter of intoxication by V. Vasiliev & $71.77 \pm 0.57$ & $54.27 \pm 0.49$ & +1 & 0.05 \\
\hline Index of cell reactivity of organism & $555.78 \pm 4.18$ & $733.79 \pm 3.47$ & -1 & 0.05 \\
\hline Lymphocytic-granulocytic index & $4.27 \pm 0.11$ & $4.09 \pm 0.07$ & +1 & $>0.05$ \\
\hline Intoxication differentiation index & $4.32 \pm 0.10$ & $4.44 \pm 0.12$ & -1 & $>0.05$ \\
\hline
\end{tabular}

index on $33.33 \%$ and tendency to the elevation of leucocytic indexes of intoxication calculating by Ya. Kal-Kalif up to $5.73 \%$ and by V. Rais on $8.63 \%$. At the same time the lymphocytic-granulocytic index increase on $4.40 \%$ certifies level of endogenous intoxication and activating of processes of cells and tissues liver disintegration increase. Endogenic intoxication triggered hepatic cells cytolysis caused by viral reproduction with subsequent immune system reaction in HCV chronic phase. From pathophysiologic point of view, this syndrome was accompanied by lipid peroxidation processes increase, blood cells damage, disorders in antioxidant and immune system activity.

\section{Conclusions}

1. Level of adaptation processes decreased on $12.20 \%$ in patients with chronic hepatitis C. The majority $(70.97 \%)$ of patients had determined in the zone of stress reaction (22.58\%) and reaction on training ( $48.39 \%$ ) by the adaptation index.

2. It have been established an evident increase of intoxication index on $33.33 \%$ and tendency to the elevation of leucocytic indexes of intoxication calculating by Ya. Kal-Kalif up to $5.73 \%$ and by V. Rais on $8.63 \%$. At the same time the lymphocytic-granulocytic index was increased on $4.40 \%$ that certifies level of endogenous intoxication increase and activation of processes of cells and tissues liver disintegration.

3. Cellular reactivity of organism of patients with chronic hepatitis $\mathrm{C}$ decreased on $32.03 \%$, that was confirmed by an increase of nuclear index of endotoxicosis level on $81.25 \%$. In general, $\mathrm{HCV}$-infected Caucasian persons was characterized by moderate endotoxicosis level accompanied by activating of processes of disintegration of cells and liver tissues.

\section{References}

[1] Garkavi, L. Kh., Kvakina, Ya. B., \& Ukolova, M. A. (1997)Adaptacionnye reakcii i rezistentnost' organizma [Adaptational reactions and resistance of organism]. Rostov na Donu: Izd. Rostovskogo universiteta. [in Russian].

[2] Golubovskaya, O.A. (2013) Virusnyj gepatit - e'to diagnoz, a ne prigovor [Viral hepatitis - it is a diagnosis, not a verdict]. Zerkalo nedeli. Ukraina, 26, 3-4. [in Ukrainian].
[3] Dmitryeva, E. V., Bueverov, A. O., Moskaleva, E. U., et al. (2001) Immunopatogenez khronicheskikh virusnykh gepatitov [Immunopathogenesis of chronic viral hepatitis]. Medicinskaya immunolokhiya, 3(2), 218-219. [in Russian].

[4] Sydorchuk, I. Y., Kaspruk, N. A., Levytska, S. A., Sydorchuk, L. I., Yakovets, K. I., Sydorchuk, A. R., \& Sydorchuk, A. S. (2015) Klitynna reaktyvníst' ta ríven' adaptatsíinoho napruzhennia organízmu khvorykh na hostryi bronkhit [Cell reactivity and stress level adaptation of the patient with acute bronchitis]. Bukovynskyi medychnyi visnyk, 19, 1(73), 154-158. [in Ukrainian].

[5] Ostrovsky, V. K., Mashchenko, A. V., Yangolenko, D. V., \& Maкarov, S. V. (2006) Pokazateli krovi i lejkocitarnogo indeksa intoksikacii v ocenke tyazhesti i opredeleniya prognoza pri vospalitel'nykh, gnojnykh i gnojnodestruktivnykh zabolevaniyakh [The parameters of blood and leukocytic intoxication index in the evaluation of the severity of inflammatory, purulent, and pyodestructive diseases] Klinicheskaya laboratornaya diagnostika, 6, 50-53. [in Russian].

[6] Speranskij, I. I., Samojlenko, G. E., \& Lobacheva, M. V. (2009) Obshchij analiz krovi - vse li yego vozmozhnosti ischerpany? Integral'nyj indeks intoksikacii kak kriterij ocenki tyazhesti techeniya e'ndogennoj intoksikacii, ee oslozhnenij i e'ffektivnosti provodimogo lecheniya [Common blood count - do all possibilities are completing? Integrative indexes of intoxication like criteria of severity assessment of indogenious intoxication, their complications and effectiveness of treatment]. Zdorov'e Ukrainy, 6(19), 51-57. [in Ukrainian]

[7] Bowen, D. G., \& Walker, C. M. (2005) Adaptive immune responses in acute and chronic hepatitis C virus infection. Nature, 436, 946-952. doi: 10.1038/nature04079.

[8] Ansaldi, F., Orsi, A., Sticchi, L., Bruzzone, B., \& Icardi, G. (2014) Hepatitis $C$ virus in the new era: perspectives in epidemiology, prevention, diagnostics and predictors of response to therapy. World J. Gastroenterol, 7, 20(29), 9633-9652. doi: 10.3748/wjg.v20.i29. 9633.

[9] Guidotti, L. G., \& Chisari, F. V. (2006) Immunobiology and pathogenesis of viral hepatitis. Annu. Rev. Pathol., 1, 23-61. doi: 10.1146/annurev. pathol.1.110304.100230.

[10] Madaliński, K., Zakrzewska, K., Kołakowska, A., \& Godzik, P. (2015) Epidemiology of HCV infection in Central and Eastern Europe. Godzik Przegl Epidemiol, 69(3), 459-464, 581-584.

[11] Rezaee-Zavareh, M. S., Hadi, R., Karimi-Sari, H., Hossein Khosravi, M. Ajudani, R., Dolatimehr, F., et al. (2015) Occult HCV Infection: The Current State of Knowledge. Iran Red. Crescent. Med. J., 17(11), 174-189.

\section{Information about authors:}

Sydorchuk A. S., MD, PhD, associate professor of Department of Internal Medicine and Infectious Diseases of HSEE "Bukovinian State medical University", Chernivtsi, Ukraine.

Moskaliuk V. D., MD, DSc, professor of Department of Internal Medicine and Infectious Diseases of HSEE "Bukovinian State medical University", Chernivtsi, Ukraine. 
Balaniuk I. V., MD, candidate of medical sciences, assistant professor of Department of Internal Medicine and Infectious Diseases of HSEE "Bukovinian State medical University",

Chernivtsi, Ukraine.

Sydorchuk L. I., associate professor, PhD, associate professor of Department of microbiology and virology of HSEE "Bukovinian State medical University", Chernivtsi, Ukraine.

\section{Відомості про авторів:}

Сидорчук А. С., канА. меА. наук, Аоцент каф. внутрішньої меАицини та інфекційних хвороб, ВАНЗ “Буковинський Аержавний медичний університет", м. Чернівці, Україна. Москалюк В. А., А-р меА. наук, професор каф. внутрішньої медицини та інфекційних хвороб, ВАНЗ "Буковинський Аержавний медичний університет", м. Чернівці, Україна. Баланюк І. В., канА. меА. наук, асистент каф. внутрішньої медицини та інфекційних хвороб, ВАНЗ “Буковинський Аержавний медичний університет", м. Чернівці, Україна. Сидорчук $\wedge$. І., канА. меА. наук, Аоцент каф. мікробіології та вірусології, ВАНЗ "Буковинський державний меАичний університет", м. Чернівці, Україна.

\section{Сведения об авторах:}

Сидорчук А. С., канА. меА. наук, доцент каф. внутренней меАицины и инфекционных болезней, ВГУЗ “Буковинский государственный медицинский университет", г. Черновцы, Украина.

Москалюк В. А., А-р меА. наук, профессор каф. внутренней медицины и инфекционных болезней, ВГУЗ “Буковинский государственный меАицинский университет", г. Черновцы, Украина.

Баланюк И. В., канА. меА. наук, ассистент каф. внутренней медицины и инфекционных болезней, ВГУЗ «Буковинский государственный медицинский университет", г. Черновцы, Украина.

Сидорчук А. И., канА. меА. наук, Аоцент каф. микробиологии и вирусологии, ВГУЗ “Буковинский государственный медицинский университет", г. Черновцы, Украина.

Конфлікт інтересів: віАсутній.

Conflicts of Interest: authors have no conflict of interest to declare.

Надійшло Ао редакції / Received: 09.11.2016

Після Аоопрацювання / Revised: 20.12.2016

Прийнято Ао Аруку / Accepted: 11.01.2017 